\title{
ANALISIS RISIKO KEGAGALAN BUDIDAYA JAMUR TIRAM PADA
} BINTAN CENDAWAN

\author{
Risk Analysis The Failure of Oyster Mushroom Cultivation On Bintan Cendawan
}

\author{
Dwi Septi Haryani ${ }^{1}$ \\ Manajemen, STIE Pembangunan Tanjungpinang \\ *)E-mail:dwiseptih@gmail.com
}

\begin{abstract}
The purpose of this study was to analyze and identify the risk of product failure of oyster mushroom cultivation, the impact caused by the risk of failure of oyster mushroom cultivation, and the actions that need to be taken in anticipation and prevention of risks that can arise in mushroom cultivation oysters in Bintan Cendawan. This study uses a descriptive qualitative research approach. The research location is on Jalan Hang Jebat Kp. Pisang RT.002 / RW.007 No.60, Kijang City, BintanTimur District, Bintan Regency. Data collection techniques used in this study were interviews and documentation. The results showed that there are several factors that can cause failure in the process of oyster mushroom cultivation, these factors consist of several levels so that the impact caused also has a scale or level of which can often occur until that never happens and also has a high or low impact. So to anticipate or avoid risk-risk that can arise, must also do certain things or be careful of production controls as the risk of product failure can be minimized.
\end{abstract}

Keywords: Risk, Product, Product Failure (Times New Roman font 9, italic)

\begin{abstract}
ABSTRAK
Tujuan dari penelitian ini adalah untuk menganalisis dan mengidentifikasi risiko kegagalan budidaya jamur tiram, dampak yang di timbulkan serta tindakan yang perlu dilakukan sebagai antisipasi dan pencegahan atas risiko-risiko pada usaha budidaya jamur tiram di Bintan Cendawan. Penelitian ini menggunakan pendekatan penelitian kualitatif deskriptif. Lokasi penelitiannya adalah di Jalan Hang Jebat Kp. Pisang RT.002/ RW.007 No.60, Kijang Kota Kecamatan Bintan Timur,Kabupaten Bintan. Teknik pengumpulan data yang digunakan dalam penelitian ini adalah wawancara dan dokumentasi. Hasil penelitian menunjukkan bahwa ada beberapa faktor yang dapat menyebabkan timbulnya kegagalan pada proses budidaya jamur tiram, faktor tersebut terdiri dari beberapa level sehingga dampak yang ditimbulkan juga memiliki skala atau tingkatan dari yang bisa sering terjadi sampai yang tidak pernah terjadi dan juga berdampak tinggi ataupun rendah. Jadi untuk mengantisipasi atau menghindari risiko-risko yang dapat timbul harus melakukan halhal tertentu terhadap kontrol produksi sebagai risiko kegagalan produk dapat di minimalisir.
\end{abstract}

Kata kunci: Risiko, Produk, Kegagalan Produk

\section{Pendahuluan}

Salah satu bidang yang memberi andil pada pertumbuhan ekonomi suatu negara adalah agribisnis yang sedang berkembang di Indonesia. Salah satunya adalah budidaya jamur tiram yang berada di wilayah Bintan. Di beberapa negara, agribisnis sangat penting, bertanggung jawab untuk generasi kerja, keseimbangan positif perdagangan (surplus perdagangan) (Bornhofen, Ramires, Bergonci, Nakamura, \& Righetto, 2019). Sesuai dengan pernyataan (Behzadi, Justin, Sullivan, Lennon, \& Zhang, 2018), bahwa Agribisnis berperan penting dalam perekonomian dunia sebagai sumber utama pasokan makanan.

Bintan Cendawan yang merupakan usaha pribadi yang membudidayakan jamur tiram yang beralamat di Jalan Hang Jebat Kp. Pisang RT.002/ RW.007 No.60, Kijang Kota Kecamatan Bintan Timur,Kabupaten Bintan. Usaha ini telah berdiri sejak awal April 2016 yang didirikan oleh Zainal. Tujuan Zainal untuk mendirikan usaha budidaya jamur tiram ini ialah untuk meningkatkan perekonomian keluarga pendiri dan untuk memenuhi permintaan konsumen akan kebutuhan jamur tiram.

Seiring perkembangan zaman usaha budidaya jamur tiram ini menjadi salah satu pusat perhatian di wilayah Kabupaten Bintan khususnya untuk di Kelurahan Kijang Kota karena usaha ini merupakan usaha yang sangat maju khususnya usaha budidaya jamur tiram.

Usaha yang dikelola oleh Zainal ini merupakan usaha yang menguntungkan dimana dengan modal yang tidak terlalu besar mampu meraup keuntungan yang maksimal. Umumnya usaha budidaya jamur tiram ini penggunaan bibitnya harus mengambil pasokan dari luar daerah namun 
berbeda dengan bibit yang digunakan oleh Zainal, ia mampu menciptakan bibit sendiri dengan kualitas terbaik. Hal inilah yang menjadikan sebuah kekuatan tersendiri dari usaha budidaya jamur tiram milik Zainal.

Namun dalam menjalankan usaha budidaya jamur tiram ini, Zainal masih menghadapi kendala yang menghambat budidaya jamur tiram. Diantaranya kegagalan dalam menciptakan bibit jamur, kualitas jamur yang tidak sesuai, jamur yang tidak dapat tumbuh dikarenakan alat yang tidak steril, human eror dan bencana banjir. Produk gagal adalah salah satu risiko yang dihadapi pada usaha Bintan Cendana. Produk gagal adalah produk yang tidak memenuhi standar kualitas yang telah ditetapkan secara ekonomis (Mulyadi, 2012).

Risiko merupakan bagian penting dari bisnis karena perusahaan tidak dapat beroperasi tanpa mengambil risiko (Fadun, 2013). Suatu hal tindakan yang dilakukan oleh seseorang pasti akan ada kemungkinan mengalami risiko. Seperti apapun tindakan yang dilakukan pasti akan terjadi sebuah risiko baik itu risiko yang besar maupun risiko yang kecil. Risiko adalah bagian yang tidak dapat dipulihkan dari proses membuat keputusan dan, dalam banyak situasi, mengambil risiko tampaknya menjadi satu-satunya strategi yang tersedia untuk mengatasi risiko (Salvo, Capitello, Gaudenzi, \& Begalli, 2019).

Bencana banjir menjadi salah satu penyebab kegagalan budidaya jamur tiram. Bahkan menurut (Bornhofen et al., 2019), bencana alam dapat mempengaruhi negara yang berbeda dengan cara yang berbeda. Masalah mengelola risiko saat ini sudah menjadi fokus (centre stage) di dalam organisasi (Ahmed \& Manab, 2016). Risiko bencana didefinisikan sebagai probabilitas yang diharapkan dari urutan atau kerugian yang diakibatkan dari interaksi antara bahaya alam atau antropogenik dan kondisi rentan, menurut Birkman et al., dalam (Hernández, Carreño, \& Castillo, 2018). Sejalan dengan pendapat yang diungkapkan (Novickyte, 2018), bahwa pendapatan pertanian tergantung pada banyak masalah lingkungan, teknologi dan tantangan ekonomi serta perubahan struktural dalam kebijakan dan lembaga pertanian. Untuk itu, (Hardaker et al., 2015) mengatakan bahwa petani harus menerapkan strategi dan instrumen untuk mengelola pendapatan dan risiko mereka dan untuk mencapai stabilitas pendapatan (Novickyte, 2018)

Berdasarkan latar belakang diatas, maka tujuan dalam penelitian ini adalah 1) untuk melakukan identifikasi risiko yang dihadapi dalam usaha budidaya jamur tiram di Bintan Cendawan, 2) untuk mengetahui dampak yang ditimbulkan dari risiko kegagalan budidaya jamur tiram pada Bintan Cendawan, 3)melakukan penilaian risiko yang dihadapi dalam usaha budidaya jamur tiram di Bintan Cendawan, dan 4) untuk mengetahui tindakan yang perlu dilakukan sebagai antisipasi dan pencegahan atas risiko dan dampak yang terjadi.

Pengertian risiko menurut kamus Oxford (2005) dalam (Nikou \& Selamat, 2013) adalah suatu situasi yang melibatkan paparan bahaya. Menurut Project Management Body of Knowledge (PMBOK) (PMI, 2008), mendefinisikan risiko sebagai kejadian yang tidak menentu atau kondisi yang, jika terjadi, memiliki efek pada setidaknya satu tujuan proyek (Porananond \& Thawesaengskulthai, 2014).
Demikian pula, standar manajemen risiko ISO31000 (2009) dan AS/NZS 4360 (2004) mendefinisikan risiko sebagai kemungkinan sesuatu terjadi yang akan berdampak pada suatu tujuan (Porananond \& Thawesaengskulthai, 2014).

Proses manajemen risiko terdiri dari: 1) Identifikasi risiko, 2) Evaluasi dan pengukuran risiko, dan 3) Pengelolaan risiko (Hanafi, 2014). Menurut (Fahmi, 2010), risiko dapat dikelola dengan empat cara, yaitu dengan meminimalkan risiko, mengalihkan risiko, mengendalikan risiko dan mendanai risiko.

Salah satu pelaksanaan manajemen risiko di perusahaan yang dikenal adalah Enterprise Risk Management (ERM). Lam (2000) mendefinisikan ERM sebagai kerangka kerja yang terintegrasi untuk mengelola risiko operasional, risiko kredit, risiko pasar, modal ekonomi, dan transfer risiko untuk memaksimalkan nilai konstan (Ahmed \& Manab, 2016). Lalu, Menurut Committee of Sponsoring Organizations (COSO) kerangka mendefinisikan Enterprise Risk Management (ERM) sebagai suatu proses, yang dipengaruhi oleh Dewan Direksi, manajemen dan personil lainnya, diterapkan dalam pengaturan strategi dan di seluruh perusahaan, dirancang untuk mengidentifikasi potensi peristiwa yang dapat mempengaruhi entitas, dan mengelola risiko berada dalam nafsu risiko, untuk memberikan jaminan yang wajar mengenai pencapaian tujuan entitas (Mustapha \& Adnan, 2015).

Penelitian terkait yang mendukung penelitian ini diantaranya penelitian yang dilakukan oleh: 1) (Wiryani, Achsani, \& Baga, 2013) yang meneliti tentang pemetaan risiko di industri penyamakan kulit dengan pendekatan ERM (Enterprise Risk Management), hasil yang ditemukan adalah a) risiko- risiko yang ditemukan dalam tahapan proses bisnis PT XYZ terkait bidang strategic, operating, reporting, dan compliance, b) besar tingkat risiko yang dialami PT XYZ tercermin pada peta risiko yang terbentuk atas pengukuran risiko berdasarkan probabilitas dan dampaknya, c) strategi yang perlu dikembangkan untuk mitigasi risiko yang efektif bagi PT XYZ diprioritaskan menangani risiko paling tinggi dulu baru kemudian ke risiko yang lebih rendah. 2) (Nikou \& Selamat, 2013) yang meneliti tentang Kemampuan manajemen risiko dalam rantai pasokan makanan Malaysia, hasil survei terkait dengan rantai pasokan makanan tertentu dan tidak menjadi generik dari semua rantai pasokan makanan.

\section{Metode Penelitian}

Penelitian ini merupakan penelitian kualitatif. Dengan menggunakan desain penelitian deskriptif dengan pendekatan kualitatif bertujuan untuk menggali mengenai fakta operasional berdasarkan pendekatan Enterprise Risk Management (ERM). Sumber data yang digunakan adalah data primer yaitu melalui wawancara dan data sekunder yang didapat dari buku referensi, dan jurnal. Teknik pengumpulan data yang digunakan dalam penelitian ini adalah wawancara, dan dokumentasi.

Objek penelitian dalam penelitian ini adalah Bintan Cendana. Ruang lingkup penelitian ini hanya pada variabelvariabel yang berkaitan dengan risiko kegagalan produk. Yang menjadi informan dalam penelitian ini adalah pemilik Bintan Cendana bernama Zainal dengan teknik pengambilan sample menggunakan purposive sampling dimana pertimbangannya adalah orang yang dijadikan sebagai 
informan yang memahami proses produksi jamur tiram pada Bintan Cendana.

\section{Hasil}

\section{Kapasitas Produksi dan Proses Budidaya Jamur Tiram}

Proses budidaya jamur tiram dilakukan setiap hari dengan kapasitas produksinya sebanyak 200 baglog per harinya. Dari 200 baglog tersebut mampu menghasilkan jamur tiram sebanyak $30 \mathrm{~kg}$.

Harga jual untuk tiap jamur tiram adalah Rp 40.000/kg. Jika dalam $1 \mathrm{kali}$ produksi maka penghasilan kotoro yang didapat adalah $\mathrm{Rp} 40.000$ x $30 \mathrm{~kg}=\mathrm{Rp}$ 1.200.000.Sementara keuntungan bersih yang diperoleh adalah $80 \%$ x Rp $1.200 .000=R p$ 960.000. Jika dalam sebulan maka keuntungan bersih yang didapat dari produksi jamur tiram adalah Rp 960.000 x 4 kali panen $=\operatorname{Rp} 3.840 .000$.

Adapun langkah-langkah dalam proses budidaya jamur tiram adalah sebagai berikut :

\section{a. F0 (kultur murni)}

Dalam proses membuat bibit (kultur murni) dibutuhkan bahan-bahan dapur seperti agar-agar, bawang merah, air tebu, dan lain sebagainya dengan biaya sebesar Rp 10.000/10 botol kultur murni. Jamur tiram dibelah menjadi dua bagian dan ditengahnya ada sejenis tangkai yang kemudian tangkai tersebut diambil menggunakan pisau yang steril sebanyak seujung kuku dan diletakkan di agar-agarnya. Sekitar dua minggu akan tumbuh membentuk sebuah jaringan.

b. F1 (membentuk jaringan)

Kultur murni yang sudah membentuk seperti jaringan tersebut diambil seujung kuku dan diletakkan kedalam botol, lama kelamaan kultur murni tadi akan berubah warna menjadi putih. Satu botol kultur murni yang telah dibuat dapat menciptakan sebanyak 100 botol F1.

c. F2 (bibit terakhir)

F1 yang sudah terbentuk menjadi padat kemudian diambil dengan menggunakan sendok besi yang sudah diberi alkohol.

d. F3 (baglog)

Dalam proses F3 ini, F2 (bibit terakhir) diletakkan diatas serbuk kayu lunak (kayu sengon) yang bersih Setelah 21 hari F2 (bibit terakhir) yang telah diletakkan pada serbuk kayu tersebut akan menebal. Saat waktu panen, F3 ini akan diembunkan dengan cara menyemprotkan air secara perlahan agar menjadi embun. Lama kelamaan F3 akan tumbuh dari sela-sela

\section{Identifikasi Risiko} botol yang telah dibungkus dengan koran.

Berbagai kemungkinan dapat terjadi dan menimbulkan risiko dalam melakukan kegiatan ataupun proses pembudidayaan jamur tiram. Risiko-risiko tersebut diantaranya:

1. Peralatan tidak steril

Kesalahan saat menggunakan peralatan yang tidak steril dalam proses budidaya jamur tiram ini dapat terjadi dikarenakan peralatan yang sudah terkontaminasi dengan partikel-partikel lain dapat menyebabkan kegagalan dalam menciptakan bibit (kultur murni). Jadi apabila bibit (kultur murni) tidak menggunakan peralatan yang benar-benar steril sudah dapat dipastikan bibit tersebut akan gagal.
2. Kebersihan diri karyawan tidak terjaga

Kebersihan diri karyawan yang tidak terjaga dapat terjadi pada saat dimana karyawan tidak mandi atau memakai wewangian yang terlalu kuat akan berdampak pada lingkungan laboratorium yang akan mempengaruhi pertumbuhan bibit (kultur murni). Bibit (kultur murni) sangat sensitif terhadap bau di lingkungan sekitarnya, dan apabila karyawan memakai wewangian sudah dapat dipastikan bibit (kultur murni) tersebut akan gagal.

3. Kesalahan dalam memilih serbuk kayu

Menggunakan serbuk kayu yang tidak bersih dalam proses budidaya jamur tiram menjadi salah satu risiko yang sangat fatal. Serbuk kayu yang tidak bersih yang dimaksudkan ialah serbuk kayu yang sudah tercampur atau terkontaminasi dengan partikel-partikel lain seperti minyak dari alat pemotong kayu. Serbuk kayu yang baik digunakan dalam budidaya jamur tiram ini adalah serbuk kayu yang tekstur kayunya lunak seperti kayu sengon, dimana kayu sengon ini merupakan kayu yang biasanya digunakan untuk membuat peti kemas. Dengan demikian untuk proses budidaya jamur tiram ini membutuhkan serbuk kayu yang bersih agar terhindar dari risiko kegagalan dalam menciptakan jamur tiram yang berkualitas baik.

4. Penyemprotan air yang terlalu kencang

Dalam proses penyemprotan ini, hanya dilakukan secara perlahan saja gunanya untuk membuat jamur tersebut lembab atau hanya mengembunkan jamur saja. Prosesnya ialah menutup di bagian dinding bangunan dengan menggunakan karung kemudian karung tersebut disemprotkan air secara perlahan untuk membuat embun, oleh karena itu budidaya jamur tiram ini tidak mengenal musim karena musimnya telah direkayasa dengan membuat dinding yang dilapisi dengan karung agar menciptakan kondisi yang lembab untuk pertumbuhan jamur tiram. Apabila menyemprotkan air yang terlalu kencang dapat menyebabkan jamur tesebut mati dan menimbulkan genangan air yang banyak dimana genangan tersebut dapat mengakibatkan tempat tumbuhnya jamur-jamur parasit yang dapat menghambat pertumbuhan jamur. Jadi gunakan air yang secukupnya saja.

5. Terjadi banjir dilokasi tempat usaha

Lokasi usaha budidaya jamur tiram ini berada pada dataran rendah, sehingga apabila saat hujan turun akan mengakibatkan banjir, hal ini juga sangat fatal karena apabila terjadi banjir sudah dipastikan produk akan gagal.

Dampak yang bisa timbul dari risiko-risiko yang terjadi

1. Mudah diserang oleh hama lalat jamur

Penggunaan peralatan dan media untuk membudidaya jamur tiram ini harus benar-benar steril. Sedikit saja peralatan yang digunakan tidak steril akan memiliki dampak yang besar terhadap proses petumbuhan jamur tiram tersebut. Media-media yang digunakan untuk budidaya jamur tiram ini memang sangat memungkinkan untuk terjadinya habitat baru bagi parasit yang dapat menghambat pertumbuhan jamur tiram seperti salah satunya penggunaan serbuk kayu. Serbuk kayu memang merupakan habitat untuk hewanhewan seperti serangga, ulat, dan sebagainya. Jadi diharapkan untuk selalu menjaga kebersihan pada 
peralatan dan penggunaan media guna untuk mencegah terjadinya hama pada jamur tiram.

2. Jamur terkena virus dan dapat menumbuhkan jamur lainnya.

Trichoderma spp merupakan nama penyakit yang dapat menyerang jamur tiram melalui udara yang disebabkan oleh kurangnya menjaga kebersihan diri pekerja dan lingkungan tempat usaha. Jamur yang terkena penyakit ini akan berubah menjadi bintik-bintik berwarna hijau pada media baglog. Usahakan pekerja untuk mandi terlebih dahulu dan tidak memakai wewangian yang terlalu kuat karena dapat menjadi salah satu faktor tumbuhnya penyakit Trichoderma spp tersebut serta menjaga kebersihan lingkungan tempat usaha untuk tidak menggenangkan air agar tidak becek karena akan memancing adanya petumbuhan jamur lainnya.

Penilaian Risiko

Adapun untuk frekuensi diambil dari angka 1-5 yaitu:

Tabel 1. Tingkat Frekuensi Kejadian

\begin{tabular}{cc}
\hline Tingkat & Kejadian \\
\hline 1 & Tidak pernah \\
\hline 2 & Jarang \\
\hline 3 & Cukup sering \\
\hline 4 & Sering \\
\hline 5 & Sangat sering \\
\hline
\end{tabular}

Sedangkan untuk dampak juga diambil angka 1-5, dengan anggapan:

Tabel 2. Tingkat Dampak

\begin{tabular}{cc}
\hline Tingkat & Kejadian \\
\hline 1 & Sangat kecil \\
\hline 2 & Kecil \\
\hline 3 & Sedang \\
\hline 4 & Besar \\
\hline 5 & Sangat besar \\
\hline
\end{tabular}

Berikut ini adalah tabel yang berisi identifikasi risiko beserta frekuensi terjadinya dan dampak yang ditimbulkan pada saat kegiatan ataupun proses budidaya jamur tiram.

Tabel 3. Identifikasi Risiko

\begin{tabular}{cccc}
\hline No. & Identifikasi Risiko & Frekuensi & Dampak \\
\hline R1 & $\begin{array}{c}\text { Peralatan tidak } \\
\text { steril }\end{array}$ & 2 & 4 \\
\hline R2 & $\begin{array}{c}\text { Kebersihan diri } \\
\text { karyawan tidak } \\
\text { terjaga }\end{array}$ & 3 & 4 \\
\hline R3 & $\begin{array}{c}\text { Kesalahan dalam } \\
\text { memilih serbuk } \\
\text { kayu }\end{array}$ & 2 & 5 \\
\hline R4 & $\begin{array}{c}\text { Penyemprotan air } \\
\text { yang terlalu } \\
\text { kencang }\end{array}$ & 2 & 4 \\
\hline R5 & $\begin{array}{c}\text { Terjadi banjir } \\
\text { dilokasi usaha }\end{array}$ & 3 & 5 \\
\hline Sumber: Hasil Olahan Data $(2019)$ &
\end{tabular}

Sumber: Hasil Olahan Data (2019)

Setelah mendapatkan hasil dari identifikasi risiko beserta frekuensi terjadinya dan dampak yang ditimbulkan, maka untuk dapat melihat dan mengetahui apakah risiko tersebut merupakan risiko dengan tingkat keparahan rendah (low), sedang (medium), dan tinggi (high), penulis melakukan kombinasi antara frekuensi terjadinya risiko dan dampak dari risiko tersebut dalam sebuah matriks dengan sumbu $\mathrm{x}$ dan y. Dalam manajemen risiko matriks seperti ini juga dikenal dengan likehood-impact matrix.

Risiko dan Dampaknya

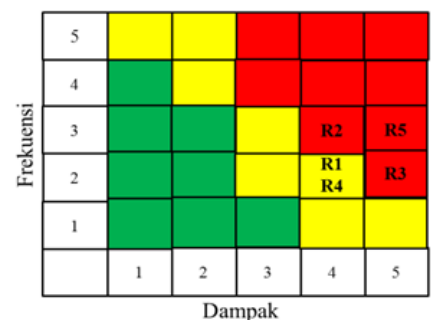

Sumber: Hasil Olahan Data (2019)

Gambar 1. Likelihood-Impact Matrix

Berdasarkan matriks diatas terdapat beberapa penjelasan yaitu:

1. Setiap kotak berwarna hijau berarti bahwa risiko tersebut berada pada tingkat keparahan rendah (low).

2. Kotak berwarna kuning berarti bahwa risiko tersebut berada pada tingkat keparahan sedang (medium).

3. Kotak berwarna merah berarti bahwa risiko tersebut berada pada tingkat keparahan tinggi (high).

\section{Respon terhadap Risiko}

1. R1 (peralatan tidak steril) merupakan risiko dengan tingkat keparahan medium atau sedang yang maksudnya ialah menimbulkan dampak yang besar meskipun tingkat frekuensi terjadinya jarang dilakukan. Dalam hal ini hanya sebagian kecil saja jamur tiram yang gagal karena peralatan yang tidak steril menyebabkan jamur tiram terserang hama lalat jamur. Sementara sebagian besar lainnya masih dalam kualitas yang diharapkan sesuai standar Bintan Cendawan.

Pencegahan yang dapat dilakukan dengan melakukan inspeksi rutin terhadap peralatan yang akan dipakai dengan menggunakan lembar kontrol yang dilakukan oleh petugas dan dilakukan secara terjadwal.

2. R2 (kebersihan diri karyawan tidak terjaga) merupakan risiko dengan tingkat keparahan high atau tinggi yang maksudnya ialahtingkat frekuensi terjadinya cukup sering dilakukan dan mampu menimbulkan dampak yang besar.

Pencegahan yang dapat dilakukan untuk mengatasi masalah tersebut dapat dilakukan dengan cara, melakukan pengecekan kepada karyawan agar karyawan yang akan memasuki ruang usaha benarbenar dalam keadaan bersih dan tidak menimbulkan aroma wewangian yang kuat. Kebersihan yang dimaksud ialah para karyawan harus mandi, menggunakan pakaian khusus digunakan untuk kegiatan operasional, bebas dari wewangian yang memiliki aroma yang kuat.

3. R3 (kesalahan dalam memilih serbuk kayu) merupakan risiko dengan tingkat keparahan high atau tinggi yang maksudnya ialah tingkat frekuensi terjadinya jarang dilakukan namun mampu menimbulkan dampak yang sangat besar.

Pencegahan yang dapat dilakukan untuk mengatasi masalah tersebut dapat dilakukan dengan cara, melakukan pemeriksaan secara teliti pada serbuk kayu yang digunakan pada saat pembelian dan jika perlu lakukan pemesan khusus untuk serbuk kayu yang terjamin kebersihan serbuk kayunya dari minyak oli atau kotoran lainnya. Serbuk kayu yang baik digunakan 
ialah serbuk kayu sengon (kayu yang digunakan untuk pembuatan peti).

4. R4 (penyemprotan air yang terlalu kencang) merupakan risiko dengan tingkat keparahan medium atau sedang yang maksudnya mampu menimbulkan dampak yang besar meskipun tingkat frekuensi terjadinya jarang dilakukan.

Pencegahan yang dapat dilakukan melalui cara mengganti alat penyemprot yang sesuai dengan ketentuan penyemprotan, dan dengan memberi pelatihan kepada karyawan dalam hal menyemprot serbuk kayu agar tidak terjadi kesalahan.

5. R5 (terjadinya banjir di lokasi usaha) merupakan risiko dengan tingkat keparahan high atau tinggi yang maksudnya ialah tingkat frekuensi terjadinya cukup sering dilakukan dan mampu menimbulkan dampak yang sangat besar.

Pencegahan yang dapat dilakukan untuk mengatasi masalah tersebut dapat dilakukan dengan cara, memperbaiki atau merenovasi tempat usaha dengan membuat lebih tinggi bangunannya dan membuat selokan disekitar tempat usaha guna terhindar dari risiko banjir di lokasi yang berdataran rendah.

\section{Kesimpulan}

Hasil penelitian menunjukkan bahwa ada beberapa faktor yang dapat menyebabkan timbulnya kegagalan pada proses budidaya jamur tiram, faktor tersebut terdiri dari peralatan tidak steril, kebersihan diri karyawan tidak terjaga, kesalahan dalam memilih serbuk kayu, penyemprotan air yang terlalu kencang dan terjadi banjir di tempat lokasi usaha sehingga dampak yang ditimbulkan memiliki skala atau tingkatan dari berdampak tinggi ataupun rendah.

Untuk mengantisipasi atau menghindari risiko-risko yang dapat timbul harus melakukan hal-hal tertentu terhadap kontrol produksi sebagai antisipasi risiko kegagalan produk. Pengelolaan risiko dapat dilakukan berdasarkan prioritas, melalui tabel likelihood-impact matrix, dapat membantu dalam pengambilan keputusan terkait pengendalian risiko. Dimulai dari yang berdampak paling besar yaitu risiko banjir, kebersihan karyawan yang tidak terjaga, dan kesalahan dalam memilih serbuk kayu menjadi prioritas utama. Lalu risiko yang berdampak medium diantaranya risiko peralatan tidak steril dan penyemprotan air yang terlalu kencang.

\section{Literatur}

Ahmed, I., \& Manab, N. A. (2016). Influence of enterprise risk management success factors on firm financial and non-financial Performance : A Proposed Model. International Journal of Economics and Financial Issues, 6(3), 830-836.

Behzadi, G., Justin, M., Sullivan, O., Lennon, T., \& Zhang, A. (2018). Agribusiness supply chain risk management : A review of quantitative decision models R. Omega, 79, 21-42. https://doi.org/10.1016/j.omega.2017.07.005
Bornhofen, E., Ramires, T. G., Bergonci, T., Nakamura, L. R., \& Righetto, A. J. (2019). Associations between global indices of risk management and agricultural development. Agricultural Systems, 173(March), 281-288. https://doi.org/10.1016/j.agsy.2019.03.006

Fadun, O. S. (2013). Risk management and risk management failure: Lessons for business enterprises. International Journal of Academic Research in Business and Social Sciences, 3(2), 225-239.

Fahmi, I. (2010). Manajemen Risiko. Bandung: Alfabeta. Hanafi, M. M. (2014). Manajemen Risiko (2nd ed.). Yogyakarta: UPP STIM YKPN.

Hernández, M. L., Carreño, M. L., \& Castillo, L. (2018). International Journal of Disaster Risk Reduction Methodologies and tools of risk management : Hurricane risk index ( HRi ). International Journal of Disaster Risk Reduction, 31(August), 926-937. https://doi.org/10.1016/j.ijdrr.2018.08.006

Mulyadi. (2012). Akuntansi Biaya. Yogyakarta: UPP STIM YKPN.

Mustapha, M., \& Adnan, A. (2015). A Case Study of Enterprise Risk Management Implementation in Malaysian Construction Companies. International Journal of Economics and Financial Issues, 5(2), 70-76.

Nikou, S. H., \& Selamat, H. (2013). Risk Management Capability within Malaysian Food Supply Chains. International Journal of Agriculture and Economic Development, 1(1), 37-54.

Novickyte, L. (2018). Income Risk Management in Agriculture using Financial Support. European Journal of Sustainable Development (2018), 7(4), 191-202. https://doi.org/10.14207/ejsd.2018.v7n4p191

Porananond, D., \& Thawesaengskulthai, N. (2014). Risk Management for New Product Development Projects in Food Industry. Journal of Engineering, Project, and Production Management, 4(2), 99113.

Salvo, M. De, Capitello, R., Gaudenzi, B., \& Begalli, D. (2019). Land Use Policy Risk management strategies and residual risk perception in the wine industry : A spatial analysis in Northeast Italy. Land Use Policy, 83, 47-62. https://doi.org/10.1016/j.landusepol.2019.01.022

Wiryani, H., Achsani, N. A., \& Baga, L. M. (2013). PEMETAAN RISIKO DI INDUSTRI PENYAMAKAN KULIT DENGAN PENDEKATAN Enterprise Risk Management ( ERM ). Jurnal Manajemen \& Agribisnis, 10(1), 5059 . 
Jurnal Ekonomi dan Bisnis Indonesia 